\title{
Global industries and local development: labour in the Malagasy garment industry
}

\author{
Nick Bernards
}

\author{
This study was conducted under the supervision of Professor Adam Sneyd \\ Department of Political Science, College of Social and Applied Human Sciences \\ University of Guelph, Guelph, Ontario, Canada
}

\begin{abstract}
This paper examines some of the challenges and opportunities for development in Africa presented by the globalization of production through a qualitative-historical case study analysis of the condition of labour in the garment industry in Madagascar. It argues that this case demonstrates that attempts to incorporate national economies into the global economy on the basis of a comparative advantage in low-value added, labour intensive industries are unlikely to lead to significant development benefits. The paper first develops a historical overview of the development of the Malagasy export garment industry. It is situated within global and local trends towards economic liberalization, the re-orientation of development finance towards foreign direct investment, and the globalization of garment production. Three main structural features of the Malagasy Zone Franche garment industry are emphasized: the centrality of low cost labour, the dominance of low value added labour intensive activities, and reliance on access to markets in the industrialized north. These structural conditions are reinforced by the fluidity and volatility of the sector. The final section considers the impacts of these structures on labour relations in the garment industry. It argues that these structural conditions have kept wages and working conditions chronically poor. This failure to improve the condition of work is indicative of the weak structural position of peripheral economies and the challenges this poses to private sector-led development.
\end{abstract}

$\mathrm{T}_{\mathrm{o} \text { o }}^{\mathrm{h}}$ globalization of production presents new opportunities and poses new challenges for economic development in Africa. The development outcomes of populations on the periphery of the global economy are increasingly shaped by the ways in which they are able to fit themselves into global networks of production. The aim of this paper is to examine the interaction of the structures of global production with local contingencies and the impacts this interaction can have for peripheral populations. This problem is addressed here with qualitative and historical case study evidence from the garment industry in the export processing zones (EPZs) in Madagascar (called the Zones Franches). Evidence is drawn from publicly available primary sources, including statistical data published by the Malagasy government, the United Nations Conference on Trade and Development (UNCTAD), the World Bank, and the International Labour Office (ILO), newspaper articles, reports published by the International Confederation of Free Trade Unions (ICFTU) and the Clean Clothes Campaign (CCC), and newspaper articles. I have also drawn heavily on previous academic literature.

In particular, I explore the connections between the structure of the global garment industry and the conditions of labour in the Zones Franches between
2000 and 2009. This time period represents to peak of activity in the Zones Franches, the Zones expanded rapidly after being granted access to the United States market through the Africa Growth and Opportunity Act (AGOA) in 2000. The country was expelled from AGOA in 2009 following a military coup. An assessment of present conditions in the sector would require field research well beyond the scope of this project. $^{\text {a }}$

In short, this paper asks two related questions. First, 'What outcomes has their incorporation into global garment production had for workers in Madagascar and why?' And second, 'what do these outcomes say about the prospects for development through similar schemes?'

This paper argues that this case demonstrates that seeking development on the basis of a comparative advantage in low value-added and labour intensive economic activities is not likely to lead to significant benefits for peripheral populations. Rather, it is likely to reinforce marginal and dependent patterns of accumulation inhibiting economic development.

The first section of this paper briefly considers the global contexts of development finance and changes in the garment industry in which this case takes place. The next three sections consider the historical development 
of the structure of Zone Franche garment sector. The final section explicitly considers the impacts of this structure on the condition of labour in the Zones Franches.

\section{GLOBAL CONTEXT}

\section{FDI and development finance}

EPZs have been a popular policy option for states seeking to attract foreign direct investment (FDI). They have become increasingly widespread in recent years. According to one estimate, the number of people employed in EPZs worldwide grew from 43 million to 66 million between 2002 and 2006 [1]. EPZs themselves are best understood as one manifestation of a general trend towards policies aimed at attracting FDI as a means of advancing development, discussed at length by a variety of authors $[2,3,4,5,6,7,8]$.

Since the Third World debt crisis in the 1980s in particular, FDI has been increasingly seen as the only viable means of financing economic development. In part this is because FDI is more in line with the neoliberal trend in development policy. In any event, there are few other viable options for southern governments. Official aid flows are perceived as too often tied up in the political objectives of donors, banks are (unsurprisingly) much less willing to lend money to Southern governments after the debt crisis, and portfolio investments are seen as too volatile [9]. The relevant point here is that, whatever the underlying reasons, developing countries since the early 1980s have generally viewed attracting direct investments from transnational corporations (TNCs) as the best (or the only) available means of achieving greater economic development.

Academic consensus in the early 1980s was that the developing world would enjoy a considerable comparative advantage attracting investments in labour intensive industries because their populations would happily work for very low wages [e.g. 10, 11, 12]. ${ }^{b}$ Though much of the empirical evidence that has emerged over the period since would seem to suggest that wages are at best a weak determinant of FDI flows [e.g. 13], these ideas have had a clear influence on policy.

\section{The globalization of garment production}

Garment production involves four distinct stages (figure 1). The first stage involves the production of fibres. These can either be produced through agriculture (as in the case of wool and cotton) or synthetically. The second stage involves the spinning and weaving of these fibres into textiles and fabrics. The third stage involves the cutting and stitching of these fabrics into garments. This stage is generally mechanized and capital intensive. Larger producers are thus able to realize considerable economies of scale. Garment assembly is not particularly suitable to mechanization, and tends to be more labour intensive, less centralized, and have considerably lower profit margins than textile production $[14,15,16,17] .{ }^{\mathrm{c}}$ Finally, garments are marketed and distributed, frequently by large TNCs with well-known brands (e.g. Wal-Mart, Nike, Adidas, Levi Strauss). These firms are able to establish standards of quality, price and speed that must be met by earlier stages of production [15]. ${ }^{\mathrm{d}}$ The globalization of garment production, then, refers to the trend since roughly the 1970s towards the fragmentation and global dispersal of these stages of activity.

From the mid 1970s onwards, employment in the garment assembly stage has rapidly been transferred to low wage jurisdictions in the developing world. This

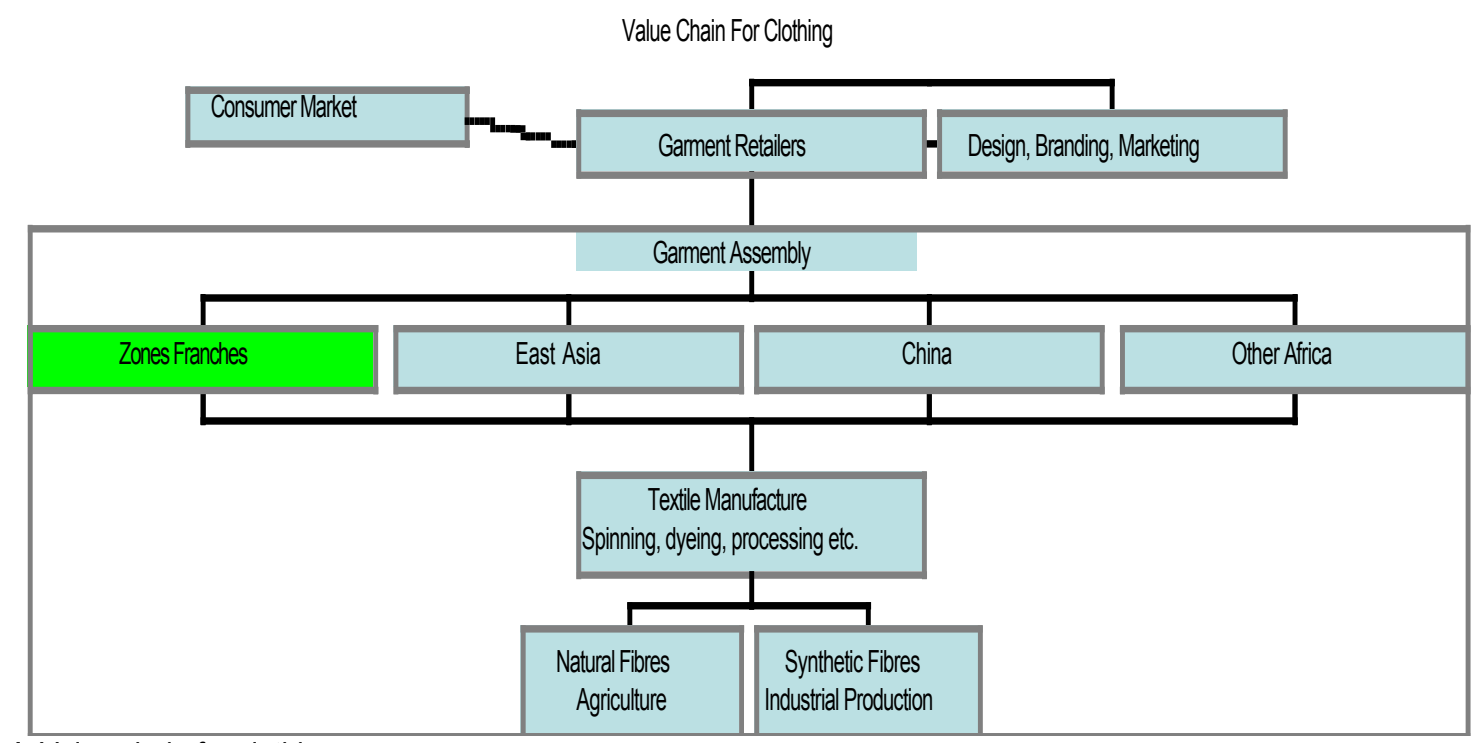

Fig 1. Value chain for clothing. 
has not been the case with the other stages of production $[14,15]$. Garment assembly operations have become increasingly fragmented, while the production of textile inputs and the distribution of finished products have become increasingly centralized. Profits margins at the assembly stage have thus tended to be very low, owing largely to very intense competition in garment assembly relative to the other stages.

The globalization of garment production has been uneven and unequal. It is specifically the low valueadded, labour intensive stages of the production process, namely garment assembly and some of the agricultural production of natural fibres like cotton and wool, that have come to take place in the global south. Textile production and garment retailing have remained relatively concentrated in the north.

\section{DEBT, LIBERALIZATION, AND THE ZONES FRANCHES}

Madagascar has been almost continuously riven by political conflict and crisis for close to 40 years. The state has held chronically low legitimacy and has often struggled to perform even the most basic functions of government. Maureen Covell dates these trends to 1972 when the country gained formal independence from France. This touched off three years of civil war, which would come to an end with General Didier Ratsiraka gaining power in 1975. In Covell's words, "the 1972 revolution marked an important change in the nature of Malagasy society: social cleavages and tensions once hidden by a 'peaceful if melancholy' appearance have, since May 1972, broken out in periodic urban riots and rural revolts" [18]. ${ }^{\mathrm{e}}$ Ratsiraka established an interventionist economic system often classified as 'socialist' or even 'Marxist'.

The government of Madagascar, however, lacked the resources to finance such a scheme. The results were disastrous. By the 1980s the island was in deep economic crisis. Ratsiraka's government found itself struggling to finance its programs, with a budget deficit in 1981 climbing to roughly 19 percent of the gross domestic product [19]. ${ }^{\mathrm{g}}$ Ratsiraka's government had clearly overextended itself.

The liberalization of the Malagasy economy, including the implementation of the Zone Franche programme, was driven by this crisis. In many southern states faced with the same problem, neoliberal ideas offered a solution promising economic growth without needing to address the difficult problem of enhancing state capacity [20]. This was undoubtedly true for Madagascar.

Ratsiraka's government, like many others in the South at the time, turned to the International Monetary Fund (IMF) for financial assistance and adopted a program of economic liberalization. This entailed a radical reorientation of the state's approach to development away from planning and public financing and toward attracting investment. The obvious model for Malagasy policy makers was neighbouring Mauritius.

Mauritius had begun its own market led development strategy, with EPZs as a central component, in the 1970s. The Mauritian development programme was exceptionally successful. Proponents frequently argue that its EPZs had enabled Mauritius to develop from a poverty stricken economy almost totally dependent on sugar exports to an diversified middleincome country $[21,22] .{ }^{\text {h }}$ By the 1980 s, the country had developed a substantial garment industry in its EPZs, to the extent that a considerable number of the firms operating there were either taken over by Mauritian owners or transferred their base of operations to Mauritius. For Malagasy policy makers, given similar assets (namely an abundant supply of cheap labour), facing crisis conditions and IMF pressure to liberalize their economy, the Mauritian success undoubtedly seemed to suggest an appealing model. The Zone Franche legislation was passed in 1989.

The influence of Mauritius is especially visible in the similarity of the two countries' EPZ policies. The main concessions to investors in the Malagasy Zones Franches were based on the Mauritian model. The Zone Franche legislation grants a substantial tax holiday and reduced import tariffs for foreign investors. Currently Zone Franche investors pay no taxes to the Malagasy government for fifteen years and a discounted rate of ten percent on all profits earned on goods produced in Madagascar afterwards [24]. Madagascar also followed Mauritius in not limiting EPZs to specific enclaves, rather allowing investors to set up anywhere on the island. In theory, anywhere a foreign manufacturer sets up in Madagascar is a Zone Franche. Despite having this freedom, however, almost all the Zone Franche factories in Madagascar are clustered around the capital, Antananarivo. This is likely largely due to the poor quality of infrastructure in the country. Even in Antananarivo, where the infrastructure is the best developed in Madagascar, apparel firms report an average of 13.7 power outages a month [25]. ${ }^{\mathrm{i}}$

Notably, unlike many EPZs, the Zones Franches have operated under the same labour legislation as the rest of the island for most of their history. There was some controversy in 2008 over provisions in an updated version of the Zone Franche legislation that were perceived by labour leaders as establishing a separate labour code in the Zones [26, 27, 28]. It is difficult to assess whether or not this new law actually had any impact on labour in the Zones Franches because it was passed only months before the country's expulsion from AGOA. In any event, however, the country's labour laws have never been especially well enforced 
(discussed below).

Investment in the Zones Franches became a crucial source of employment in Madagascar. The largest foreign investor in monetary terms in Madagascar, Shell Exploration and Development Madagascar, employed all of sixty-six Malagasy workers in 2002. The two largest foreign-owned employers, in terms of employees, in 2006 were a French rubber manufacturer and a South African-owned company that had exclusive license to operate the country's railways. The next four largest foreign employers in order were all Zone Franche garment manufacturers. Further, these were the only other foreign firms with upwards of one thousand Malagasy employees and the only significant employers on the list who had actually established new operations rather than taking over privatizing state businesses [29]. The Zones Franches have proven attractive to international garment producers.

The policy features discussed here remained in place for the entire time period in which the Zone Franche legislation has been in effect, with a few relatively minor amendments. The substantial developments over the course of the period have largely been the result of changes to the relevant international trade regimes, the instability of the Malagasy political regime, and volatility in the global markets for textile inputs and finished garments. I deal with these developments in the following subsection.

\section{WAVES OF INVESTMENT AND THE STRUCTURE OF THE ZONES FRANCHES}

The Zones have attracted two main waves of investment, both driven primarily by exogenous factors. The first took place in the mid-1990s, coming mainly from Mauritius. The second wave took place in the early 2000s, originating from Asian and American firms and driven by the implementation of AGOA by the American Congress. Three main structural features of the Zones Franches emerged through these successive waves. First, investments in the sector primarily seek out cheap labour. Second, investments remain largely restricted to the labour intensive assembly stage of garment production. These first two have been clearly evident throughout the history of the Zones Franches. Third, these investments are dependent on access to markets in the developed north. This third feature has become more evident with the second wave of investment spurred by AGOA.

\section{The first wave: Mauritian investments}

The position of the Mauritian garment industry in the early 1990s largely explains the first wave of investment in the Zones Franches. Mauritian garment firms found themselves squeezed between rapidly consolidating global retailers, intensifying competition among garment manufacturers, and rising input prices. Mauritian firms were further faced with escalating labour costs.

Some Mauritian garment manufacturers tried to respond to these pressures by establishing their own brands with consumers in Europe in a bid to increase the prices they could command. However, given their limited resources, the sheer distance of the major world markets in Europe and North America, and the very high barriers to entry into the more profitable activities of branding and retailing, it is not surprising that these efforts failed [30]. ${ }^{\mathrm{j}}$

Cutting labour costs by moving some or all of their assembly activities to Madagascar's Zones Franches proved to be a more sustainable solution to the problem. Wages in Madagascar are less than a third of the rate in Mauritius, and indeed are among the lowest in the world [31, 32]. The relatively low cost of labour in Madagascar remains centrally important to the Zones Franches. The activity in the Zones remains limited to garment assembly, and low wages remain the chief driver of investment.

This homogeneity is problematic. Garment firms operating in Madagascar overwhelmingly cut and stitch garments, only a small few produce textiles. Further, the few textile-manufacturing firms present on the island deal entirely in cotton and other natural fibres, with no production of more profitable synthetic fibres taking place [33]. ${ }^{\mathrm{k}}$ In any event, the country's capacity to produce apparel is more than twenty times greater than its ability to produce textiles [25]. ${ }^{1}$ An overwhelming proportion of the investment in the Zones is courtesy of garment assembly firms trying to relieve the pressures of rising costs upstream and shrinking prices downstream by cutting labour costs. ${ }^{\mathrm{m}}$ The lack of textile production also means that the firms in Madagascar have to rely heavily on imported inputs (discussed below).

Cheap labour, then, has become deeply entrenched as a part of the structure of the Zone Franche sector. Global competition in garment production, especially from China, is intense [35]. The Zones Franches are, for the producers who invest in them, a means of alleviating some of the pressure on their profit margins from that competition. The poor conditions of labour in the Zones Franches (discussed in detail in below) are thus not a matter of unethical exploitation but rather a structural condition.

This is not to suggest that suppliers are necessarily benevolent towards their workers, or that given the opportunity they would pay them any more than they do. Notwithstanding the intentions of garment manufacturers, however, the structure of the garment industry is such that manufacturers have little choice in terms of the labour costs they can take on. This point is borne out by the fact that labour conditions have not 
changed appreciably over the period in which the Zones Franches have operated, despite the involvement of a wide variety of firms as investors in the Zones and buyers of its products.

\section{The second wave: trade regimes and Malagasy garments}

Thus, the first two key structural features of the Zone Franche garment industry, that is, cheap labour and the predominance of assembly operations, were largely established by the first wave of investments. The third has become especially apparent with the second wave of investments. The early Mauritian and French investors in the Zones produced almost entirely for the European market, although even then some of the larger Mauritian firms had begun to seek relationships with American buyers [36]. The country's quotas under the Multi-Fibre Agreement (MFA) more or less dictated the flow of goods out of the Zones. Even cheaply produced goods stand little chance of being competitive in markets intentionally protected from them.

The MFA, in Underhill's words, was "the most spectacular and comprehensive protectionist agreement in existence and became accepted practice within the trade regime" [14]. ${ }^{\mathrm{n}}$ The MFA represented an explicitly political intervention into the otherwise rapidly globalizing production of textiles and garments. It was negotiated and implemented mainly at the behest of developed country governments (especially France) seeking to prevent the erosion of their domestic garment and textile industries [14]. An agreement was reached at the conclusion of the Uruguay Round of negotiations on the General Agreement on Trade and Tariffs in 1994 to phase out the MFA over a period of ten years.

This development, however, was problematic for Madagascar's garment producers. Madagascar's quotas under the MFA, while imposing limits on exports, also granted it access to northern markets for production up to its quota. Madagascar's productive capacity at the time was not nearly high enough to meet its quotas. Thus, its MFA quotas did not represent a limitation on exports in practice [37]. Further, by limiting exports from other parts of the world, the quotas gave Malagasy garments some protection from competition from Asia.

Some African products at the time did have the advantage of preferential access to the European market under the Lomé Convention,. However, Zone Franche garments benefited little in terms of EU market access from the Lomé Convention largely because that agreement included multi-stage rules of origin for manufactured goods not met by the products of the Malagasy garment industry, which continued to rely on imported textiles. For a period, then, the imminent dismantling of the MFA left the future of the Zones in considerable doubt [37]. ${ }^{\circ}$

For these reasons, the Zones Franches were dramatically transformed by the implementation of AGOA and its Special Rule for Apparel, both of which gave firms operating in Madagascar access to the American market. AGOA is an American act of Congress administered by the President, and not a trade agreement. The Special Rule for Apparel grants quota and duty free access to the United States market for apparel manufactured in qualifying Sub-Saharan African countries.

Importantly, in contrast to the EU's Lome Convention, the AGOA Special Rule for Apparel includes different rules of origin for different groups of countries. Products of the 'least-developed beneficiary countries' (LDBCs), which include Madagascar, need only to be assembled in a beneficiary country. For nonLDBCs, including Mauritius, the rules of origin are more rigorous [38].

AGOA's looser rules of origin had two implications. First, firms could benefit from American market access without having to rely on the decidedly inadequate local production of key inputs in Madagascar. Second, Mauritian firms were given an added incentive to move even more production to Madagascar because in doing so they could gain access to the United States market that would not be available for goods produced in Mauritius.

AGOA thus spurred more investment from Mauritius along with a considerable diversification of the home countries of Zone Franche investors. Firms from East Asia were especially prominent [37]. There were also some firms already operating in Madagascar's Zones who sought new opportunities in the American market through AGOA [39].

The impact of American market access on the garment industry in Madagascar was thus considerable. In the words of the head of the Groupement des Entreprises Franches et Partenaires (GEFP- the business association for Zone Franche investors): "I would say that everyone who ships to the U.S. commenced their operations in Madagascar because AGOA was in place" [qtd. 40]. While this statement is doubtless somewhat hyperbolic, it is nonetheless a useful indication of the perceived significance of AGOA to Madagascar. Exports to the United States did undoubtedly grow appreciably under AGOA, much more so than in almost any other African countries [37, $41]^{\mathrm{p}}$

With this second wave of investment stemming from AGOA, the contemporary structural features of the Malagasy Zone Franche sector were more or less established. ${ }^{\mathrm{q}}$ First, investors generally set up in Madagascar in search of cheap labour. Second, factories in Madagascar almost exclusively assemble garments rather than produce textiles or retail the 
finished products. Third, investors depend on favourable access to northern markets, particularly access to the United States market through AGOA. These features are reinforced by the mobility and volatility of the sector. Because the assembly stage of garment production is highly competitive and extremely mobile, any change in these structural conditions is likely to provoke the withdrawal of investments from the Zones Franches.

\section{CRISES AND VOLATILITY}

Considerable evidence to support this claim can be found in the recent history of the sector, particularly in three major crises in 2002, 2007, and 2009 respectively.

Input sourcing arrangements are highly fluid, and depend on the particular firm and product in question. Whatever their origin, however, it is notable that virtually all material inputs are imported. Different reports have made mention of wool from Australia, cotton fabric from Lesotho, and cotton and synthetic textiles from any of South Africa, China, East Asia, or the United States [25, 33, 42, 43, 44]. The salient point here is that, aside from most of the buttons and embroidery used [25] and the cotton fabric coming from the few textile producers on the island, the Zone Franche factories rely on imported inputs. Relationships with buyers are equally fluid and contingent [45]. Despite the fact that particular suppliers tend to be oriented toward particular markets and particular products, they nonetheless do not normally have especially longstanding relationships with buyers.

The fluidity of these commercial relationships is best demonstrated by the volatility of the sector. Since the implementation of AGOA, the sector has gone through two acute crises from which it recovered with striking speed.

The first of these was almost entirely domestic in its origins. A stalemated presidential election in December of 2001, pitting Ratsiraka against thenmayor of Antananarivo Marc Ravalomanana, came close to plunging the country into civil war. Ravalomanana, who by most accounts won at least the largest plurality of votes if not an outright majority, declared himself president and took control of the capital city. Ratsiraka disputed the results of the election and went as far as to set up a rival government in the city of Tamatave and call on provincial governors to declare themselves independent [46]. Ratsiraka's supporters set up blockades on most roads leading to Antananarivo. One of these blockades cut off the only route from the capital to the country's lone port in Toamasina. Without any means of delivering its products for shipment overseas or bringing foreign inputs to the factories, the Zone Franche sector virtually shut down. ${ }^{\mathrm{r}}$ Thus, when access to foreign markets was cut off, the sector was unable to operate.

Perhaps more striking than the speed with which the sector collapsed, though, was that with which it resumed production after the political crisis was resolved. In 2001, 54800 people were employed in the Zone Franche, the figure for 2002 was less than half that: $21600{ }^{\mathrm{s}}$ By 2003 the figure had recovered to almost exactly pre-crisis levels [51]. The pace with which production resumed is a considerable testament to the fluidity and volatility of the relationships between Zone Franche suppliers and global buyers. Production was halted almost entirely, and buyers managed to source their clothes from elsewhere without difficulty. Yet, when the crisis was resolved and the roadblock between Antananarivo and Toamasina removed, Zone Franche investors were able to find new contracts very quickly.

Thus, the 2002 crisis was the result of a domestic shock. In a sense garment manufacturers operating in Madagascar were able to benefit from the flexibility of their relationships with retailers by quickly resuming production.

However, on at least one occasion since their dependence on a volatile global market has proved problematic for Zone Franche investors. In late 2007 a sharp drop in demand for Malagasy garments led to considerable layoffs across the Zone Franche sector [52]. While it has not been unusual for individual employers to layoff a considerable proportion of their employees when not under contract with a particular buyer, such coinciding layoffs across much of the sector have been rare. That said, the sector recovered quickly from this crisis too. In short, the relationships between Zone Franche producers and global buyers are very fluid, and in 2002 and 2007 this has had sectorwide consequences.

The third, as yet unresolved, crisis was sparked by the ejection of Madagascar from AGOA in 2009. Without access to the vital American market, the sector seems to have contracted substantially [53; 54]. Here again, a change in a key structural condition provoked a rapid shutdown of production.

This volatility is significant because it helps to reinforce the structural position of the Zones Franches. Any major changes that violate the key structural terms of the sector are likely to provoke rapid de-investment.

These structural traits, namely the dependence on cheap labour, the dominance of labour intensive low value-added activities, and the need for favourable trade regimes (outlined above), have to a considerable impact shaped the position of labour in the sector. They have been reinforced by the mobility and volatility of the sector. They have remained constant despite major changes to the orientation of the sector brought on by the passage of AGOA. Up to this point I have outlined 
the structural terms on which Malagasy workers have been incorporated into the global garment industry. The rest of this paper will examine the outcomes of this incorporation for workers in the Zones Franches in more detail.

\section{LABOUR IN THE ZONES FRANCHES}

The condition of labour is a useful place to explore the impacts of these structural conditions on potential development outcomes because workers are the segment of the Malagasy population most directly engaged with the garment industry. Ultimately, given the very limited taxes charged to Zone Franche operators and the lack of commercial linkages to the rest of the country's economy, if the Zone Franche strategy is to have positive development impacts these will have to come through the wages and benefits granted to the workers in the sector. Unfortunately, the evidence examned here offers little reason for optimism.

In broad terms, Madagascar is fairly reflective of pan-African trends in labour relations. Horwitz identifies several features of labour policy-making in the continent as a whole. A few of these are clearly visible in Madagascar: a restrictive atmosphere for unions, heavy collaboration with the International Labour Office in formulating policy, and the progressive liberalization of labour regimes since the 1980s [55].

As is the case in many EPZs globally, the labour force is predominantly young and female, wages are very low, rates of unionization are minimal and conditions are often very poor. The employees in the Zones are roughly 70 percent female $[56,57]$. The high proportion of women in the labour force is not insignificant. Indeed, it would seem to fit with a broader trend towards the 'feminization' of low skill jobs identified by some writers [58, 59]. However, lacking detailed information on the importance of gender in the hiring practices of firms, different employment preferences of men and women in Madagascar, and information on gendered differences in pay, status, or conditions in the Zones Franches, I cannot comment effectively on the importance of gender here. ${ }^{\mathrm{t}}$

Wages remain low in large part because of chronic under- and unemployment in Madagascar [61, 62]. More than half of the working population of Antananarivo is engaged in the informal sector at the best of times, and indeed from 2002-2006 that proportion hovered between 58 and 60 percent [51]. The labour force of the Zones Franches is drawn from this population. According one worker from the Zones: "You only look for a job in an EPZ factory when you've exhausted all hope of finding one anywhere else. For many women it's the only way to escape unemployment, short of becoming a street vendor" [qtd. 63]. ${ }^{u}$ The general academic consensus is much the same. Most writers argue that the Zone Franche workers would be working in the even more precarious informal sector without their jobs in the Zones [56, 61, $64,65]$. This is further borne out by the fact that in both 2002 and in 2010 when employment in the Zones has plummeted there has been an observable corresponding rise in the proportion of the population of Antananarivo engaged in informal work [51]. In short, foreign garment manufacturers have never lacked for a surplus of workers willing to work for very little in Madagascar.

Wages are nonetheless higher in the Zones than in the country on average. This is somewhat misleading, however, for two reasons. First, the country average is strongly distorted because of the predominance of the informal sector. The Zones Franches are the worst paying formal sector of the economy [51]. Second, though they may be better rewarded than informal sector workers, Zone Franche workers make very little, on average the equivalent of 40 US dollars a month. Indeed, a considerable proportion of Zone Franche employees, at least 35-40 percent, make less than the (already very low) statutory minimum wage [51].

The Zones Franches do provide some degree of benefits not available to workers employed by domestic firms. Indeed more Zone Franche workers have access to company medical service than even public sector workers [66]. As Cling et al. point out, however: "Doubtless, this favorable treatment of Zone Franche employees, albeit relative, should not be attributed to the company heads' philanthropic tendencies, given that their main reason for setting up in Madagascar was the low cost of labor" [64]. ${ }^{\mathrm{w}}$ The relevance of these slightly higher wages and benefits is also attenuated by the very high rates of turnover in the Zones. Many employees are quite young, the jobs are seen as a last resort, and few entertain any ambition of continuing to work in the sector for long.

The high rate of turnover is also likely partly related to the work itself. The work is generally difficult and relations with management are often very poor. Zone Franche employees work on average 53.9 hours a week [66]. The local press has used the word 'miserable' on a number of occasions to describe working conditions $[67,68]$. Relations with management are often poor. As one Zone Franche worker puts it [69]:

The problem is the relationship between the employer and the workers ... we have no dialogue with our employer. He says what has to be done and we simply have to do it. When our employer talks to us it is always very harshly. And when we ask a favour, like 
raising the table a little because we have a pain in our chests from bending over, he tells us off.

Factory managers have little incentive to foster good relationships with workers because they have access to a considerable pool of unemployed or underemployed labour. Workers tend to leave rather than seek to improve conditions.

The instability of the workforce and occasional intimidation by factory management [67] have also combined to prevent any significant union presence from developing in the Zones. The proportion of Zone Franche workers in unions has consistently hovered around 14 percent [70]. In 2005 only one employer in the Zones Franches had actually signed a collective bargaining agreement [71]. The Malagasy government, whether through inability or unwillingness, has been criticized for failing to adequately protect freedom of association in the country at large, and especially in the Zones Franches [72, 73, 71].

An interesting comparison with respect to unionization might briefly be made to Lesotho, another significant AGOA garment producer. Union density is considerably higher; close to fifty percent of workers are members in the Lesotho Clothing and Allied Workers' Union [74]. Two points are important. First, evidently unionization is not totally determined by structural constraints. The global structure of the garment industry is the same for Lesotho as for Madagascar, and yet the outcomes in terms of worker organization are very different between the two cases. The structure of production in the garment industry undoubtedly functions to inhibit effective organization, but structural constraints interact with local contingencies and ultimately with individual agency. In contrast, however, outcomes in terms of wages and conditions of work are little better in Lesotho than in Madagascar [74]. While structural pressures do not necessarily prevent unionization, isolated organization on the periphery of the clothing industry seems to have had little impact on the distribution of income through the structure of production.

In sum then, it would seem that the outcomes of incorporation into global garment production for labour in the Malagasy Zones Franches have been poor. Further, these outcomes are connected to the structural terms on which that incorporation has taken place. Madagascar participates in the global production of garments as a source of cheap labour for low valueadded activities. Though the Zones Franches certainly did not create the pool of surplus labour from which they draw, they have also failed to have any really positive development outcomes because they are structurally inhibited from raising the cost of labour. The inability of the Zones to attract much investment in higher value added sectors has further reinforced the importance of cheap labour. Given the mobility and fragmentation of investments in garment assembly, neither state intervention nor independent organization on the part of workers themselves seems to offer much hope of improvement.

The reliance on access to northern markets has had less direct impacts on labour, but it does nonetheless underline the limited control over the development outcomes of the Zones Franches held by Malagasy workers and policy makers. The sector is only viable if its products can be sold to markets beyond the control of Malagasy workers and policy makers. The success of the Zones Franches thus depends on political arrangements often negotiated without their input (as $n$ the case of AGOA). Its products can also only be profitably sold to retailers controlling access to those markets if labour is poorly rewarded.

The Zones Franches thus face something of a paradox. As long as wages and work conditions remain poor, the contribution of the Zones to Malagasy development will be limited at best. However, any serious attempts to improve wages and working conditions run the risk of shutting the Zones down altogether. In any event, given the historical weakness of the Malagasy state and the lack of effective labour organization in the Zones, no such effort to raise wages is likely forthcoming.

\section{Conclusion}

The Zones Franches have failed to make a significant contribution to Madagascar's development because Malagasy populations continue to be able to participate in the global garment industry only through the most labour intensive and low-value activities. While the state has managed to attract relatively large amounts of FDI through the Zones Franches, these investments have failed to make a significant contribution to Malagasy development. ${ }^{\mathrm{x}}$ The persistently poor conditions of labour are indicative of the core problem with this strategy. Competing for investment on the basis of a comparative advantage in a marginal sector of economic activity has served only to reinforce the marginal, volatile, and dependent position of the Malagasy population in the global economy. The persistence of poor labour conditions, volatility, and the dominance of low value assembly activities in the Zones Franches despite significant political shifts domestically and in the global trade regime stands as strong evidence that the Zone Franche strategy has indeed reinforced the structural position of Madagascar's economy in the world.

This case would seem to indicate that development strategy can ill-afford to overlook the structural position of a country's economic activities. Comparative advantage can be a trap when a particular population's 
advantage lies in marginal and low-value economic activities. In such cases, as in Madagascar, simply pursuing investments in those areas of comparative advantage will likely reinforce undesirable patterns of activity rather than spurring economic development. Development will require developing the means of acquiring new capacities and the means of capturing a greater share of global production. This case, unfortunately, offers few suggestions as to how that might be possible. Further, the persistently weak Malagasy state will likely not have the capacity to implement policies along these lines at any point in the near future. Nonetheless, real economic development will not be possible without the development of some means of doing so, whether by the state, the private sector or through international institutions

${ }^{a}$ Indeed, in the period since the original submission of this article, a South-African brokered compromise seems to have been reached between the major antagonists in the dispute, though to my knowledge Madagascar has not been readmitted to AGOA at the time of writing.

${ }^{\mathrm{b}}$ Lal p. 148; Dunning p. 90; Kirkpatrick \& Nixon p. 34

${ }^{\mathrm{c}}$ Porter p. 43; Gereffi pp. 101-102; Underhill p. 34

${ }^{\mathrm{d}}$ This picture is undoubtedly somewhat simplified. A number of services (e.g. sourcing, transport, design, marketing) are contracted out by retailers and other firms along the value chain. Nonetheless, these other functions are less important for the purposes of this paper and the outline here nonetheless captures the basically most important functions in garment production.

e p. 1

f Indeed, Covell's book is part of a series on 'Marxist' political economies. Ratsiraka's Madagascar, however, was never part of the Soviet Bloc.

${ }^{\mathrm{g}}$ p. 187

${ }^{\mathrm{h}}$ It should be pointed out that while the Mauritian development success is unquestionable, not all commentators are as willing to credit the EPZ strategy for that success as the writers cited here. For instance, Joseph Stiglitz sees education spending as the most important driver of Mauritian development. Nonetheless, insofar as it is relevant to the case under consideration, the key feature of Mauritian policy emulated by Malagasy decision makers was the EPZs [23].

${ }^{i}$ p. 3.6

j pp. 138-140

${ }^{\mathrm{k}}$ p. 10

${ }^{1}$ p. 4.23

$\mathrm{m}$ Madagascar is not necessarily unique in this respect, based on interviews with workers and management from EPZs in a number of countries Raworth and Kidder argue that garment manufacturers tend to pass along the costs of competing with each other on cost and speed to workers [34].

${ }^{\mathrm{n}}$ p. 4

${ }^{\circ}$ p. 1809

$\mathrm{p}$ The only others to take advantage of the Special Rule for Apparel to a comparable extent are Lesotho and possibly Swaziland.

$\mathrm{q}$ This is, of course, notwithstanding the uncertainty surrounding the sector and indeed the entire country since 2009.

${ }^{\mathrm{r}}$ For detailed accounts of the electoral crisis see Marcus \& Razafindrakoto 2003a; Marcus \& Razafindrakoto 2003b; and Randrianja 2003 [47, 48, 46]. For an assessment of the economic damage caused by the crisis, see Cherel-Robson \& Minden 2002 [49]. It is worth mentioning in passing that it was also Ravalomanana who was ousted from the presidency in 2009. He continues to claim the right to the presidency from exile in South Africa [50].

${ }^{\mathrm{s}}$ The figure for 2002 is an average of all twelve months. The fact that it is not entirely negligible reflects the production that took place before the road was cut off and the beginnings of the recovery of the sector.

$\mathrm{t}$ One recent French study finds that economic downturns in Malagasy urban areas disproportionately affect women [60]. However, this study is focused on poverty rather than employment conditions and wages as such. Indeed, if women are disproportionately employed in an economically significant sector especially vulnerable to fluctuation, like the Zones Franches, the fact that they might be overall more impacted by downturns than men should follow almost automatically.

u p. 39

${ }^{\mathrm{v}}$ The figure quoted here is for the formal private sector as a whole. Given that the Zones Franches are the worst remunerated segment of the formal private sector this estimate is likely low, but to my knowledge it is the best available.

${ }^{\mathrm{w}}$ p. 798

'I would emphasize the word 'relative'. While the domestic importance of the Zones Franches is considerable, Africa as a whole features only marginally in worldwide FDI flows. The continent captured roughly 5 percent of global FDI inflows in 2009. Much of this money went to resource rich countries like Angola, Egypt, South Africa, Nigeria, and Sudan. Madagascar attracted more FDI than most African countries, but still drew inflows of less than one billion United States dollars [75]. 


\section{REFERENCES}

1. International Labour Office (ILO) (2009). Gender Equality at the Heart of Decent Work. Geneva: International Labour Office.

2. Bennel, Paul (1997). "Foreign Direct Investment in Africa: Rhetoric and Reality". SAIS Review 17(2): 127-139.

3. Benito, Gabriel R. \& Rajneesh Narula (2007). Multinationals on the Periphery. New York: Palgrave Macmillan.

4. Dunning, John H. (2005). "The United Nations and Transnational Corporations: A Personal Assessment". In Ludo Cuyvers and Filip De Beule. Transnational Corporations and Economic Development. New York: Palgrave Macmillan. 11-37.

5. Kumar-Bhauvik, Sumon \& Ralitza Dimova (2009). "Economic Reforms as a Tool to Attract Foreign Direct Investment: Is it a Chimera?". Applied Economics Letters 16: 951-957.

6. Lall, Sanjaya (2004). "Selective Industrial and Trade Policies in Developing Countries: Theoretical and Empirical Issues". In Soludo, Charles C., Osita Ogbu \& Ha-Joon Chang (eds.). The Politics of Trade and Industrial Policy in Africa: Forced Consensus?. Trenton, N.J. and Ottawa: International Development Research Section.

7. Lall, Sanjaya and Rajneesh Narula (2004). "Foreign Direct Investment and its Role in Economic Development: Do We Need a New Agenda?". The European Journal of Development Research 16(3): 447-464.

8. Sumner, Andrew (2005). "Is Foreign Direct Investment Good for the Poor? A Review and Stocktake". Development in Practice 15(3-4): 269-285.

9. Thun, Eric (2008). "The Globalization of Production". In John Ravenhill (ed.). Global Political Economy $2^{\text {nd }}$ ed. Oxford: Oxford University Press.

10. Lal, Deepak (2002). The Poverty of 'Development Economics' $3^{\text {rd }}$ ed. London: The Institute for Economic Affairs.

11. Dunning, John H. (1981). International Production and the Multinational Enterprise. London: George Allen \& Unwin.

12. Kirkpatrick, C. H. and F. I. Nixon (1983). The Industrialization of Less Developed Countries. Manchester: Manchester University Press.

13. Lall, Sanjaya (1998). "Changing Perspectives of Foreign Direct Investment in Development". in P.K.M. Tharakan and D. Van Den Bulke (eds.). International Trade, Foreign Direct Investment and the Economic Environment. New York: St. Martin's Press. pp. 101-134.
14. Underhill, Geoffrey R. D. (1998). Industrial Crisis and the Open Economy: Politics, Global Trade and the Textile Industry in the Advanced Economies. London: Macmillan Press Ltd.

15. Gereffi, Gary (1994). "The Organization of Buyer-Driven Global Commodity Chains: How U.S. Retailers Shape Overseas Production Networks". In Gereffi, \& Korzeniewicz, M. (eds.). Commodity Chains and Global Capitalism. Westport, Connecticut; London: Greenwood Press.

16. Porter, Tony (2002). Techonology, Governance and Political Conflict in International Industries. New York; London: Routledge.

17. Gereffi, G., Humphrey, J. \& Sturgeon, T. (2005). "The Governance of Global Value Chains". Review of International Political Economy 12(1): 78-104.

18. Covell, Maureen (1987). Madagascar: Politics, Economics and Society. London; New York: Frances Pinter.

19. Hugon, Phillipe (1986). "La Crise Economique a Madagascar et l'Intervention du Fonds Monetaire International". Canadian Journal of Africa Studies/Revue Canadienne des Etudes Africaines 20(2): 186-218.

20. Woods, Ngaire (2006). The Globalizers: The IMF, The World Bank, and Their Borrowers. Ithaca: Cornell University Press.

21. Kinunda-Rutashobya, Lettice (2003). "Exploring the Potentialities of Export Processing Free Zones (EPZs) for Economic Development in Africa: Lessons from Mauritius". Management Decision 41(3): 226-232.

22. Sawkut, Rojid, Sannassee Vinesh \& Fowdar Sooraj (2009). "The Net Contribution of the Mauritian Export Processing Zone Using Cost Benefit Analysis". Journal of International Devlopment 21: 379-392.

23. Stiglitz, Joseph E. (2011, March 7). "The Mauritius Miracle". Project Syndicate. Retrived From: http://www. projectsyndicate.org/commentary/stiglitz136/English.

24. "Redonnez Confiance aux Opérateurs". (2007, December 21). Madagascar Tribune. Retrieved from: http://www.madagascartribune.com/Redonner-confiance-auxoperateurs, 3696.html.

25. Freund, Kimberlie and Joshua Levy (2009). SubSaharan African Textile and Apparel Inputs: Potential for Competitive Production. Washington D.C.: United States International Trade Commission.

26. International Trade Union Confederation (2008). "Internationally Recognized Core Labour 
Standards in Madagascar". Report for the WTO General Council Review of the Trade Policies of Madagascar, Geneva.

27. "Nouvelle Loi sur les Zones Franches: La Conférence des Travailleurs de Madagascar Dénonce". (2008, January 31). Madagascar Tribune. Retrieved from: http:/www. madagascar-tribune.com/La-Conference-des-

Travailleurs-de,4488.html.

28. "Degradation de Respect des Droits Syndicaux". (2008, April 19). Madagascar Tribune. Retrieved from: http://www.madagascartribune.com/Degradation-du-respect-desdroits, 6128.html.

29. United Nations Conference on Trade and Development (UNCTAD) (2006). World Investment Directory- Country Profile: Madagascar. New York; Geneva: United Nations.

30. Gibbon, Peter and Stefano Ponte (2005). Trading Down: Africa, Value Chains and the Global Economy. Philadelphia: Temple University Press.

31. Cadot, Olivier \& John Nasir (2001). "Incentives and Obstacles to Growth: Lessons from Manufacturing Case Studies in Madagascar". World Bank, Regional Program on Enterprise Development Working Paper 117.

32. "Une Employée Touche 200000 Ariary". (2008, May 16). Madagascar Tribune. Retrieved from: http://www.madagascar-tribune.com/Un-employetouche-200-000-ariary,6412.html.

33. Multilateral Investment Guarantee Agency (MIGA) (2006). Snapshot Africa- Madagascar: Benchmarking FDI Competitiveness. Washington D.C.: World Bank Group.

34. Raworth, Kate and Thalia Kidder (2009). "Mimicking 'Lean' in Global Value Chains: It's the Workers Who Get Leaned On". In Bair, Jennifer (ed). Frontiers of Commodity Chain Research. Stanford, California: Stanford University Press.

35. Villoria, Nelson B. (2009). "China and the Terms of Trade of African Exporters". Journal of African Economies 18: 781-823.

36. "Interview of Mr. Vigier De Latour, Director of Floreal Knitwear and Chairman of the Mauritius Export Processing Zone Association". (1999) World Investment News. Retrieved from: http://www.winne. com/mauritius/to03.html\#INTERVIEW

37. Gibbon, Peter (2003a). "The Africa Growth and Opportunity Act and the Global Commodity Chain for Clothing". World Development 31(11): 1809-1827.

38. Africa Growth and Opportunity Act (AGOA) (n.d.)- Retrieved from: http://www.agoa.gov/ index.asp
39. Cooper, Helene. (2002, January 3). "For African Nations, Trade Bill Alters Thread of Economic Fate --- Textiles and Optimism Soar in Madagascar, but Unanswered Questions Loom --'If I Wasn't Here, I Would Be in the Rice Fields"'. Wall Street Journal Europe.

40. Lough, Richard. "Loss of Trade Deal Could Sink Madagascar Textiles". (2009, July 17). Reuters. Retrieved from: http://www.reuters.com/article /idUSLH725702

41. Butcher, Arona (2002). U.S. Trade and Investment With Sub-Saharan Africa, $3^{\text {rd }}$ Annual Report. Washington, D.C.: United States International Trade Commission.

42. Regional Agriculture Trade Expansion Support (RATES) Program (2005). Cotton-TextileApparel: Value Chain Report Madagascar. Nairobi: RATES Centre.

43. Salinger, Lynne (2003). Competitiveness Audit of Madagascar's Cotton, Textiles and Garment Sector. Arlington, Virginia: Nathan Associates Limited/USAID Madagascar.

44. "Industrie de Textile: Enquete sur la Compétivité de Madagascar". (2009, August 31). Madagascar Tribune. Retrieved from: http://www.madagascartribune.com/Enquete-sur-la-competitivitede, 14632.html.

45. de Haan, Esther \& Miriam Vander Stichele (2008). Footloose Garment Investors in Southern and Eastern Africa. Amsterdam: Stichting Onderzoek Multinationale Ondernemingen (SOMO).

46. Randrianja, Solofo (2003). "BBe Not Afraid, Only Believe': Madagascar 2002". African Affairs 102: 309-329.

47. Marcus, Richard R. \& Paul Razafindrakoto (2003a). "Participation and the Poverty of Electoral Democracy in Madagascar". Africa Spectrum 38(1): 27-48.

48. Marcus, Richard R. \& Paul Razafindrakoto (2003b). "Madagascar: A New Democracy". Current History: 215-221.

49. Cherel-Robson, Milasoa \& Bart Minten (2002). "Impact de la Crise Politique sur the Bien Etre des Menages: les Resultats d'une Evalutation par des Focus Groups Communaunx". Policy BriefProgramme ILO. Ithaca, New York: Cornell University and International Labour Office.

50. Philip, Rowan (2011, March 5). "Exiled Malagasy President Tells of His Strife, Hope" Retrived From:

http://www.timeslive.co.za/sundaytimes/article949 815.ece/Exiled-Malagasy-president-tells-of-hisstrife-hope.

51. Institut National de la Statistique (INSTAT) [Madagascar] (2010). Policy Brief-La Marche du 
Travail dans l'Agglomeration d'Antananarivo en 2010: Une Mise en Perspective Décennale. Antananarivo: INSTAT \& DIAL.

52. "Licenciement Massif Dans les Zones Franches". (2007, December 28). Madagascar Tribune. Retrieved from: http://www.madagascartribune.com/Licenciement-massif-dans-leszones, 3784.html.

53. Pourtier, Gregoire (2010, March 21). "Madagascar Crisis Puts Thousands Out of Work". Mail and Guardian Online. Retrieved from: http://www.mg.co.za/article/2010-03-21madagascar-crisis-puts-thousands-out-of-work.

54. "Entreprises en Zone Franche: Inquiétudes et Espoirs" (2009, October 15). Madagascar Tribune. Retrieved From: http://www.madagascartribune.com/Inquietudes-etespoirs, 12914.html.

55. Horwitz, Frank (2007). "Cross-Continental Trends and Issues in Employment Relations in Africa". In Geoffrey Wood and Chris Brewster. Industrial Relations in Africa. Houndmills, Basingstoke, Hampshire; New York: Palgrave Macmillan.

56. Glick, Peter \& Francois Roubaud (2006). "Export Processing Zone Expansion in Madagascar: What are the Labour Market and Gender Impacts". Journal of African Economies 15: 722-756.

57. Groupement des Entreprises Franches et Partenaires (GEFP) (n.d.). "La Situation de L'Emploi et les Conditions de Travail dans les EF". Retrieved from: http:/www.gefp.com/ madagascar_emploi.php,

58. Brynin, Malcolm (2006). “Gender, Technology \& Jobs". British Journal of Sociology 57(3): 437453.

59. Standing, Guy (1999). "Global Feminization Through Flexible Labour: A Theme Revisited". World Development 27(3): 583-602.

60. Lachaud, Jean-Pierre (2010). "Quand la Pauvreté Affecte Plus les Villes, Affecte-t-Elle Plus les Femmes? The Cas de Madagascar". Revue d'Economie du Développement 2: 73-100.

61. Glick, Peter (1999) "Patterns of Employment and Earnings in Madagascar". Cornell Food and Nutrition Policy Program Working Paper No. 92.

62. Ministere de L'Economie, des Finances et du Budget [Madagascar] (2006). Enquete Aupres des Ménages 2005: Rapport Principal. Antananarivo: Republic of Madagascar.

63. Perman, Sarah, Laurent Duvillier, Natacha David, John Eden \& Samuel Grumiau (2004). Behind the Brand Names: Working Conditions and Labour Rights in Export Processing Zones. International Confederation of Free Trade Unions.

64. Cling, Jean-Pierre, Mireille Razafindrakoto \& François Roubaud (2007a). "Export Processing Zones in Madagascar: The Impact of the
Dismantling of Clothing Quotas on Employment and Labour Standards". Développement: Institutions et Analyses de Longe-Terme [DIAL]Document de Travail 2007-06.

65. Cling, Jean-Pierre, Mireille Razafindrakoto \& François Roubaud (2007b). "Export Processing Zones in Madagascar: a Success Story Under Threat?". World Development 33(5): 785-803.

66. Cling, Jean-Pierre, Mireille Razafindrakoto \& François Roubaud (2009). "Export Processing Zones in Madagascar: The Impact of the Dismantling of Clothing Quotas on Employment and Labour Standards". In Raymond Robertson, Drusilla Brown, Gaelle Pierre \& Maria SanchezPuerta (eds.). Globalization, Wages, and the Quality of Jobs: Five Country Studies. Washington: World Bank. 237-264.

67. "La Zone Franche: Plus Que Miserable Selon une Employée". (2008, January 15). Madagascar Tribune. Retrieved from: http://www.madagascartribune.com/Plus-que-miserable-selonune,4133.html.

68. "Une Zone Industrielle dans un Marais de Misere”. (2008, May 9). Madagascar Tribune. Retrieved from: http://www.madagascartribune.com/Une-zone-industrielle-dansun, 6482.html.

69. International Confederation of Free Trade Unions (ICFTU) (2004a). "Transcript: Portrait of Norosoa Ravalanirina and Sahondra Rasolonirima". Retrieved from: http://www.icftu.org/display document.asp? Index $=991220900 \&$ Language $=\mathrm{EN}$.

70. ILO (2007). La Situation $d u$ Secteur des Entreprises Franches a Madagascar. Geneva: ILO.

71. ICTFU (2006). "Madagascar: Annual Survey of Violations of Trade Union Rights: 2006". Retrieved http://www.icftu.org/displaydocument.asp? Index $=991223897 \&$ Language $=\mathrm{EN}$.

72. ICFTU(2001). "Internationally Recognized Core Labour Standards in Madagascar". Report for the WTO General Council Review of the Trade Policies of Madagascar, Geneva

73. ICFTU (2004b). "Madagascar: Annual Survey of Violations of Trade Union Rights: 2004". Retrieved from: http://www.icftu.org/displaydocument.asp? Index $=991219447 \&$ Language $=\mathrm{EN}$.

74. Gibbon, Peter (2003b). “AGOA, Lesotho's 'Clothing Miracle' \& the Politics of Sweatshops". Review of African Political Economy 30(96): 315320.

75. UNCTAD (2010). World Investment Report 2010. New York; Geneva: United Nations. 